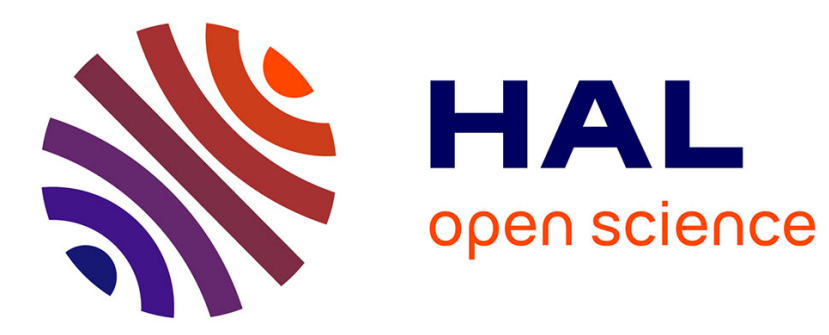

\title{
Point sampling the abundance of European eel (Anguilla anguilla) in freshwater areas
}

Pascal Laffaille, Cédric Briand, Denis Fatin, Denis Lafage, Emilien Lasne

\section{To cite this version:}

Pascal Laffaille, Cédric Briand, Denis Fatin, Denis Lafage, Emilien Lasne. Point sampling the abundance of European eel (Anguilla anguilla) in freshwater areas. Archiv fur Hydrobiologie, 2005, 162 (1), pp.91-98. 10.1127/0003-9136/2005/0162-0091 . hal-02683260

\section{HAL Id: hal-02683260 \\ https: / hal.inrae.fr/hal-02683260}

Submitted on 1 Jun 2020

HAL is a multi-disciplinary open access archive for the deposit and dissemination of scientific research documents, whether they are published or not. The documents may come from teaching and research institutions in France or abroad, or from public or private research centers.
L'archive ouverte pluridisciplinaire HAL, est destinée au dépôt et à la diffusion de documents scientifiques de niveau recherche, publiés ou non, émanant des établissements d'enseignement et de recherche français ou étrangers, des laboratoires publics ou privés. 


\begin{tabular}{lllll}
\hline Arch. Hydrobiol. & 162 & 1 & $91-98$ & Stuttgart, January 2005 \\
\hline
\end{tabular}

\title{
Point sampling the abundance of European eel (Anguilla anguilla) in freshwater areas
}

\author{
Pascal Laffaille ${ }^{1,2 \star}$, Cédric Briand ${ }^{3}$, Denis Fatin ${ }^{3}$, Denis Lafage ${ }^{2}$ \\ and Emilien Lasne ${ }^{2}$
}

With 2 figures

\begin{abstract}
The European eel population is in decline. Urgent management actions are required. To monitor their effect, we developed a fast sampling method, applicable in shallow rivers and tributaries. We compared the Carle \& Strub estimator from $35 \mathrm{dou}-$ ble pass electric fishing samples with Point Abundance Sampling by Electrofishing or PASE (24 point samples on average by section) which we adapted for the eel. The correlation between both methods was highly significant $\left(\mathrm{r}^{2}=94 \%, \mathrm{p}<0.001\right)$ for densities lower than 150 eels $\cdot 100 \mathrm{~m}^{-2}$. PASE, being a cheaper sampling method, thus constitutes an efficient and cost-effective method for evaluating management actions and further biological studies.
\end{abstract}

Key words: Anguilla, stock, monitoring, electrofishing, methodology.

\section{Introduction}

The population of the European eel (Anguilla anguilla L.) has declined throughout its distribution range (MORIARTY \& DEKKER 1997, LOBON-CERVIA 1999, DEKKER 2003). ICES (1998) recommended the implementation of a stock recovery plan, with measures addressing all inland water life stages. Several studies have attempted to estimate the size of the stocks, using methods based on fishery surveys or commercial landings data (ARDIzzone \& Corsi 1985, Feunteun et al. 1998, DeKKer 2000 a). Among the many sampling methods used to assess population density (gillnets, poisoning, hydro-

\footnotetext{
' Authors' addresses: Fish-Pass, 8 allée de Guerlédan, ZA Parc Rocade Sud, 35135 Chantepie, France.

${ }^{2}$ Université de Rennes 1, ERT: Biodiversité Fonctionnelle et Gestion des Territoires, Campus Beaulieu, 35042 Rennes, France.

3 Institution d'Aménagement de la Vilaine, 56130 La Roche-Bernard, France.

* Author for correspondence; E-mail: fishpass@fish-pass.fr
} 
acoustics, electrofishing, etc.; see Brosse et al. 2001), the most common technique is the depletion sample or survey removal data (Cowx 1983) associated with electrofishing (Cowx \& LAMARQue 1990, LAMBERT et al. 1994). However, this method is biased, imprecise (ZALEwSKI 1985, Cowx 1983), time consuming and expensive in both manpower and equipment (LOBON-CERVIA \& Utrilla 1993, Prévost \& Baglinière 1995). Moreover, the eel population is scattered among a multitude of streams, and each of these streams may be considered to have an independent eel population, depending on local accessibility and mortality factors (DEKKER 2000 b). Monitoring eel stocks may therefore require a large number of sampling points. Since data from a large number of small random samples provide more precise estimates and are more statistically robust than those from a small number of large samples (BLONDEL et al. 1970, CopP 1990), a new sampling methodology should be proposed.

Several authors have proposed 'light techniques' to determine fish stock density, especially for salmonids (STRANGE et al. 1989, BütTIKER 1992, LoBON-CERVIA \& UTRILla 1993). One of the most common methods, in freshwater research, is the Point Abundance Sampling by Electrofishing (PASE) technique (NELva et al. 1979). This rapid and cheap method provides reproducible and quantitative samples, and hence permits temporal and spatial comparisons, within and between stations (COPP 1989). We have adapted the PASE technique to the eel and propose a rapid method for estimating freshwater eel stocks in shallow rivers tributaries. This new method is validated by comparison with the standard depletion method.

\section{Materials and methods}

\section{Study site}

Samplings were conducted on tributaries of the Vilaine, in slow-flowing lowland streams, with macrophytes, and a fine gravel substrate. The Vilaine watershed covers $10400 \mathrm{~km}^{2}$, covering $1 / 3$ of Brittany (N.W. of France). The mainly schist geology is associated with impermeable soils and causes considerable variations in river flow, with severe floods in winter and low water in summer. Most of the streams have been degraded through hydraulic re-profiling. Modification of landscape and loss of plant cover on the border of streams due to intensive agriculture have created considerable silt loads. The sampling points consisted of narrow (mean width $=3.7 \mathrm{~m}$, sd $=1.66$ ) and shallow (mean depth $=0.26 \mathrm{~m}$, sd $=0.12$ ) sectors. The habitats consisted of $15 \%$ pools (slow-deep), $35 \%$ glides (slow to fast-non-turbulent) and $50 \%$ riffles (shallow and fast-turbulent).

\section{Sampling procedures}

Electrofishing was conducted in stream sections $30 \mathrm{~m}$ long, with a surface area about $120 \mathrm{~m}^{2}\left(\right.$ mean $\left.=122 \mathrm{~m}^{2}, \mathrm{sd}=31.8\right) .35$ river sections were sampled in September from 
1998 to 2001. A 'Heron' apparatus was used and delivered direct current (150 to $365 \mathrm{~V}$ and 0.8 to $6 \mathrm{~A}$ ).

Eels were caught during two consecutive electrofishing passes using a modified Point Abundance Sampling by Electrofishing (PASE) technique (Nelva et al. 1979). Upon arrival at each point, the anode was immediately placed on the bottom of the stream and was kept turning in an area of $1 \mathrm{~m}^{2}$ for at least 30 seconds. This duration corresponded to the minimum time for obtaining a response from the eels present near to the anode (see FeunTEun 1994). Fish were then collected with several fine-mesh dipnets. A total of 829 points were sampled ( $23.7 \pm 6$ per river section). Electrofishing was conducted in an upstream direction to prevent the 'contamination' of downstream samples.

This sampling design requires the presence of at least three people: the first with the electroshocker, the second with the dipnet and the third on the bank to note the results. The first pass was used to evaluate the mean density of eel by PASE (expressed as number per sampling point).

Secondly, a standardised depletion method (LAMBERT et al. 1994, FEUNTEUn et al. 1998) was used to estimate eel density (expressed as number $\cdot 100 \mathrm{~m}^{-2}$ ) from the CARLE \& STRUB (1978) estimator with two consecutive electrofishing passes. The Carle \& Strub estimator was the method that produced the more statistically reliable estimates (Cowx 1983), especially for eels (i. e., LAMBERT et al. 1994, FEUNTEUN et al. 1998).

All eels caught were measured (total length, to the nearest $\mathrm{mm}$ ), kept in tanks and released inside the sampled area immediately after the second pass.

\section{Analysis}

The mean abundance per sampling point (expressed as number of eel by sampling point) was modelled from the CARLE \& STRUB density estimator (expressed as number $\cdot 100 \mathrm{~m}^{-2}$ ) by linear regression. This regression modelling was carried out in three steps. First, a model calibration was performed using data from the Vilaine. Second, the model was tested using a 'leave-one-out' cross validation (Jacknife procedure; EFRON 1983) to assess the prediction capabilities of the linear regression. This procedure was appropriate because the data set was quite small and/or each sample was likely to have 'unique information' relevant to the regression model (RumElHART et al. 1986). Thirdly, the validation of our results was performed using an independent data matrix in order to determine the predictive quality of the model. We used 9 samples from the Arguenon River (northern Brittany) where a similar sampling was conducted.

All determination coefficients were used to quantify the ability of the model to produce the right answer. The Fisher $F$ value was used to test the model significance $\left(r^{2}\right)$ and t-tests were used to test the significance of the slope. A Kolmogorov-Smirnov one sample test (Lillefors option) was used to test the residual normal distribution.

\section{Size selectiveness}

PASE is known to be size-selective (CopP 1989) and especially the probability of capture by electrofishing could differ according to eel size classes (NAISMITH \& KNIGHTS 1990, LAMBERT et al. 1994). The relative abundance of different fish size classes, col- 
lected using the two sampling passes in the Vilaine River, were compared using a Kolmogorov-Smirnov two-sample test.

\section{Results}

A total of 1350 eels were collected. Eel densities estimated by the CARLE \& STRUB method ranged between 0.43 eels $\cdot 100 \mathrm{~m}^{-2}$ and 208 eels $\cdot 100 \mathrm{~m}^{-2}$ (mean $\pm \mathrm{sd}=46.9 \pm 57.3$ eels $\cdot 100 \mathrm{~m}^{-2}$ ). With the PASE method, eel densities ranged between 0.05 eels per sampling point and 4.13 eels per sampling point (mean $\pm \mathrm{sd}=1.23 \pm 1.31$ eels per sampling point). However, only two eel density data points were higher than 150 eels $\cdot 100 \mathrm{~m}^{-2}$. Consequently, analyses were made only using densities of $<150$ eels $\cdot 100 \mathrm{~m}^{-2}$.

Using linear regression we could predict eel density (Carle \& Strub - expressed as number $\cdot 100 \mathrm{~m}^{-2}$ ) according to mean abundance per sampling point (Point Sampling - expressed as number per sampling point):

Carle \& Strub $=35.088 \pm 1.666 \times$ Point Sampling

The model provided good predictions of eel densities in the Vilaine river (training data set, $\mathrm{r}^{2}=0.94, \mathrm{p}<0.001$; testing data set, $\mathrm{r}^{2}=0.94, \mathrm{p}<0.001$ ) and the Arguenon river (validation data set, $\mathrm{r}^{2}=0.94, \mathrm{p}<0.001$ ) (Fig. 1).

Total eel length ranged from $70 \mathrm{~mm}$ to $800 \mathrm{~mm}$ (mean \pm sd $=219 \pm$ $119 \mathrm{~mm}$ ). There was no significant difference (Kolmogorov-Smirnov two-sample test, $\mathrm{KS}=0.047, \mathrm{p}=0.631$ ) in eel size distribution between eel sampling during the first and the second pass (Fig. 2).

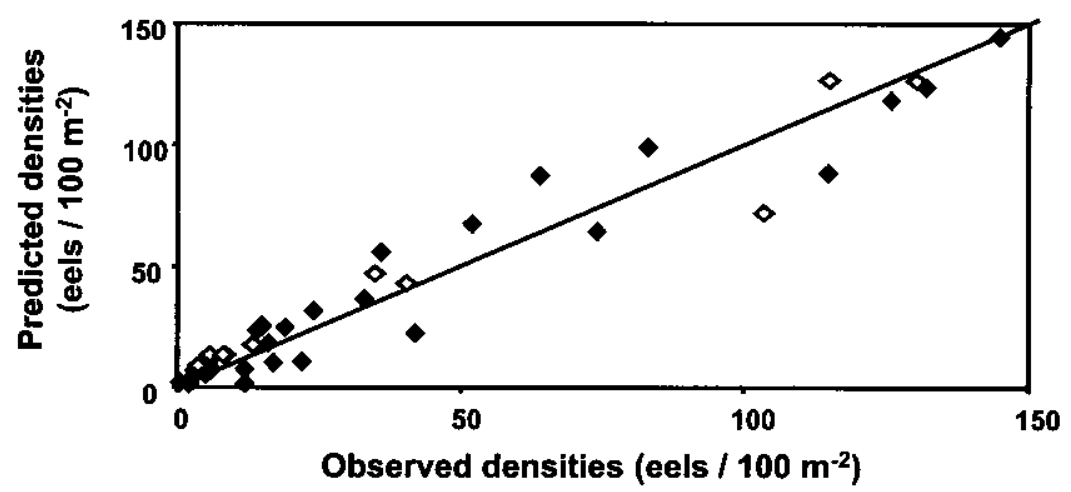

Fig. 1. Scatter plot of predicted densities (eel densities estimated by linear regression model) versus observed densities (eel densities estimated by the Carle and Strub method). Black squares $=$ training data set from the Vilaine, white squares $=$ validation data set from the Arguenon. The solid line indicates the diagonal of best prediction (coordinates 1:1). 


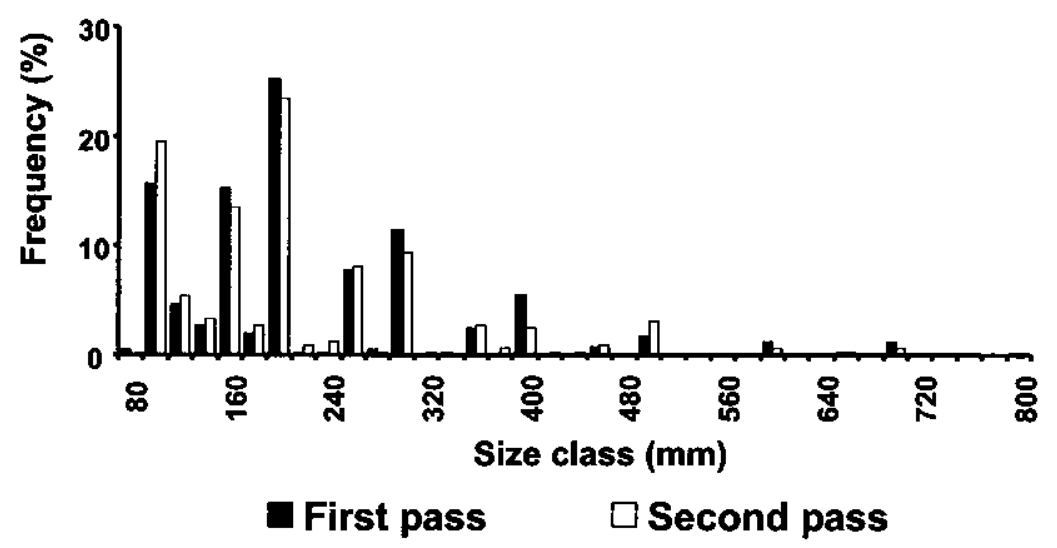

Fig. 2. Eel population structure (percentage frequency of each size class) caught during the first and the second pass.

\section{Discssion}

Cowx et al. (2001) recommended that PASE should not be used alone but in conjunction with other sampling methods (for example seine netting) to assess quantitatively the status of the 0-group fish population. However, as long as a sufficient number of samples is taken from a wide range of habitats, the size distributions in catches will be representative of the target population. Moreover, increasing sample size and stratified sampling procedures reduce the variance about mean density estimates (Copp 1989, Persat \& CopP 1990, Copp \& Garner 1995, Perrow et al. 1996, Garner 1997). Thus, PASE can be used to produce data pertaining to fish population parameters, such as size structure, density estimates and cohort strengths. Many authors (e. g., CoPP 1989, Persat \& Copp 1990, Copp \& Garner 1995, Perrow et al. 1996, Garner 1997) have subsequently advocated PASE as an efficient and cost-effective method for assessing fish abundance and population structure. In a large river, PERSAT \& COPP (1990) noted that with only 25 point samples, which represent a tiny area within a large stretch of river, a 'stable' image of taxocenose structure can be obtained. However, GARNer (1997) suggested that great care should be taken when interpreting data collected by PASE, and that 50 point samples is the minimum required for reliable estimates of fish density. In our study, we estimated that with 25 point samples per sector, a reliable estimate of eel density index was obtained in shallow streams. Moreover the density index was related to densities calculated from standard electrofishing procedures. The adjustment of such a relation was also emphasized by other authors concerning salmonid populations (STRANGE et al. 1989, BüTTIKER 1992, Lobon-Cervia \& Utrilla 1993, Prévost \& Nihouarn 1999). 
The validity of this index depends both on the standardization of the unit sampling effort and on the constancy of fish capturability. The standardisation of the sampling protocol (electrofishing in $1 \mathrm{~m}^{2}$ for at least 30 seconds) guarantees the production of a generalized index. Moreover, the use of a single passage avoids the problems of changes in capturability during successive passages (Aprahamian 1986, Lobon-Cervia \& Utrilla 1993, Lambert et al. 1994).

This methodology was effective for predicting densities lower than 150 ind. $100 \mathrm{~m}^{-2}$. Higher densities occur rarely and were generally the consequence of the concentration of small eels in sectors of riffles with a high cover of vegetated substratum (LAFFAILLE et al. 2003) or immediately downstream from migration obstructions (FEUNTEUN et al. 1998). It is time and cost effective and provided an unbiased size structure. However, the relation [number of eels per $100 \mathrm{~m}^{2}$ (Carle and Strub estimator) $=35.09 \pm 1.67$ mean number of eel per sampling point] corresponds to a single type of electroshocker (the 'Heron' working at $150-365 \mathrm{~V}$ and $0.8-6 \mathrm{~A}$ ) working in small (mean width $=3.7$ ) and shallow rivers (mean depth $=0.26 \mathrm{~m}$ ). Other similar relations could be developed for use on a wider range of equipment and habitats.

\section{Acknowledgements}

This study was supported by the Conseil Supérieur de la Pêche, Loire-Bretagne river agency, European Union, National and Regional funds. We thank J. P. PORCHER and D. Boussion for their help in setting up electrofishing stations and the CSP brigades for conducting a part of electrofishing operations. We warmly thank the anonymous referees for their comments and corrections to the manuscript.

\section{References}

APRAHAMIAN, M. W. (1986): Eel (Anguilla anguilla L.) production in the River Severn, England. - Pol. Arch. Hydrobiol. 33: 373-389.

Ardizzone, G. D. \& CoRSI, F. (1985): Eel population structure, dynamics and fishing yield in a Mediterranean coastal lagoon. - Oebalia 11: 547-560.

Blondel, J., Ferry, C. \& Frochot, B. (1970): La méthode des indices ponctuels d'abondance (IPA) ou des relevés d'avifaune par "stations d'écoute". - Alauda 38: $55-71$.

Brosse, S., Laffaille, P., Gabas, S. \& LeK, S. (2001): Is scuba sampling a relevant method to study fish microhabitat in lakes? Examples and comparisons for three European species. - Ecol. Freshwat. Fish. 10: 138-146.

BüTTIKER, B. (1992): Electrofishing results corrected by selectivity functions in stock size estimates of brown trout (Salmo trutta L.) in brooks. - J. Fish Biol. 41: 673684.

Carle, F. L. \& Strub, M. R. (1978): A new method for estimating population size from removal data. - Biometrics 35: 621-630. 
CopP, G. H. (1989): Electrofishing for fish larvae and juveniles: equipment modifications for increased efficiency with short fishes. - Aquacult. Fish. Managem. 20: 453-462.

- (1990): Shifts in the microhabitat of larval and juvenile roach, Rutilus rutilus $\mathrm{L}$. in a floodplain channel. - J. Fish Biol. 36: 683-692.

COPP, G. H. \& GARNER, P. (1995): Evaluating the microhabitat use of freshwater fish larvae and juveniles with point abundance sampling by electrofishing. - Folia Zoologica 44: 145-158.

Cowx, I. G. (1983): Review of the methods for estimating fish population size from survey removal data. - Fish. Managem. 14: 67-82.

Cowx, I. G. \& Lamarque, P. (1990): Fishing with electricity, applications in freshwater fisheries management. - Fishing news books. - Blackwell Science, Oxford, UK.

CowX, I. G., NunN, A. D. \& HARveY, J. P. (2001): Quantitative sampling of 0-group fish populations in large lowland rivers: point abundance sampling by electric fishing versus micromesh seine netting. - Arch. Hydrobiol. 151: 369-382.

DEKKER, W. (2000a): A procrustean assessment of the European eel stock, - ICES J. Mar. Sci. 57: 938-947.

- (2000 b): The fractal geometry of the European eel stock. - ICES J. Mar. Sci. 57: 109-121.

- (2003): Did lack of spawners cause the collapse of the European eel, Anguilla anguilla? - Fisheries Manag. Ecol. 10: 365-376.

EFRON, B. (1983): Estimating the error rate of a prediction rule: some improvements on cross-validation. - J. Amer. Stat. Assoc. 78: 316-331.

Feunteun, E. (1994): Le peuplement piscicole du marais littoral endigué de Bourgneuf-Machecoul (France, Loire-Atlantique). Approche méthodologique pour une analyse quantitative de la distribution spatiale du peuplement piscicole et de la dynamique de certaines de ses populations. - PhD thesis. Rennes (France): University of Rennes 1 .

Feunteun, E., Acou, A., Guillouët, J., Laffaille, P. \& Legault, A. (1998): Spatial distribution of an eel population (Anguilla anguilla L.) in a small coastal catchment of Northern Brittany (France). Consequences of hydraulic works. - B. Fr. Pêche Piscic. 349: 129-139.

GARNER, P. (1997): Sample sizes for length and density estimation of $0+$ fish when using point sampling by electrofishing. - J. Fish Biol. 50: 95-106.

ICES (1998): European eel. - Extract of report of the Advisory Committee on Fishery Management No. 11. Copenhagen (Denmark): ICES.

Laffaille, P., Feunteun, E., Baisez, A., Robinet, T., Acou, A., Legault, A. \& LEK, S. (2003): Spatial organisation pattern of European eel (Anguilla anguilla L.) in a small catchment. - Ecol. Freshwat. Fish 12: 254-264.

Lambert, P., Feunteun, E. \& Rigaud, C. (1994): Eel study in freshwater marshes. First analysis of catch probability observed during electric fishing operations. - B. Fr. Pêche Piscic. 335: 111-122.

LoBon-CERvia, J. (1999): The decline of eel Anguilla anguilla (L.) in a river catchment of northern Spain 1986-1997. Further evidence for a critical status of eel on Iberian waters. - Arch. Hydrobiol. 144: 245-253. 
Lobon-Cervia, J. \& Utrilla, C. (1993): A simple method to determine stream trout (Salmo trutta L.) densities based on one removal with electrofishing. - Fish. Res. 15: $369-373$.

Moriarty, C. \& DekKer, W. (eds) (1997): Management of European eel fisheries. Irish Fish. Bull. 15.

NaISmith, I. A. \& KNIGHTs, B. (1990): Studies of fyke netting, electrofishing and other sampling methods and of techniques for estimating populations of eels, $\mathrm{An}$ guilla anguilla $\mathrm{L}$. - Aquacult. Fish. Managem. 21: 357-363.

Nelva, A., Persat, H. \& Chessel, D. (1979): Une nouvelle méthode d'étude des peuplements ichtyologiques dans les grands cours d'eau par échantillonnage ponctuel d'abondance. - C. R. Acad. Sc. III-Vie 289: 1295-1298.

Perrow, M., JowitT, A. J. D. \& Zambrano Gonzales, L. (1996): Sampling communities in shallow lowland lakes: point-sample electric fishing vs. electric fishing within stop nets. - Fish. Managem. Ecol. 3: 303-314.

PERSAT, H. \& COPP, G. H. (1990): Electric fishing and point abundance sampling for the ichthyology of large rivers. - In: Cowx, I. G. (ed.): Developments in electric fishing. Fishing News Books Ltd.- Blackwell Scientific Publications, Oxford, pp. 203-215.

Prévost, E. \& BagliniÈre, J. L. (1995): Présentation et premiers éléments de mise au point d'une méthode simple d'évaluation du recrutement en juvéniles de saumon atlantique (Salmo salar) de l'année en eau courante. - In: Gascuel, D., DuRAND, J. L. \& FonTENEAU, A. (eds): Les recherches françaises en évaluation quantitative et modélisation des ressources halieutiques. - Orstom Editions, Paris, pp. 39-48.

Prévost, E. \& Nihouarn, A. (1999): Relation entre indicateur d'abondance de type CPUE et estimation de densité par enlèvement successifs pour les juvéniles de saumon atlantique (Salmo salar L.) de l'année. - B. Fr. Pêche Piscic. 352: 19-30.

RumelhaRT, D. E., Hinton, G. E. \& Williams, R. J. (1986): Learning representations by back-propagating error. - Nature 323: 533-536.

Strange, C. D., Aprahamian, M. W. \& Winstone, A. J. (1989): Assessment of a semi-quantitative electric fishing sampling technique for juvenile Atlantic salmon, Salmo salar L., and trout, Salmo trutta, in small streams. - Aquacult. Fish. Managem. 20: $485-492$.

ZaLEWSKI, M. (1985): The estimate of fish density and biomass in rivers on the basis of relationships between specimen size and efficiency of electrofishing. - Fish. Res. 3: 147-155.

Submitted: 8 March 2004; accepted: 20 July 2004. 